\title{
Stem Cell Treatments for Parkinson's Disease
}

\author{
Thomas Benjamin Stoker ${ }^{1,2,3}$
}

${ }^{1}$ John van Geest Centre for Brain Repair, Department of Clinical

Neurosciences, University of Cambridge, Forvie Site, Cambridge, CB2 OPY,

UK; ${ }^{2}$ Wellcome Trust - Medical Research Council Stem Cell Institute,

University of Cambridge, UK; ${ }^{3}$ Department of Neurology, Cambridge

University Hospitals NHS Foundation Trust, UK

Author for Correspondence: Thomas Stoker, John van Geest Centre for

Brain Repair, Department of Clinical Neurosciences, University of Cambridge, Forvie Site, Cambridge, CB2 OPY, UK; E-mail: tbs26@cam.ac.uk

Doi: http://dx.doi.org/10.15586/codonpublications.parkinsonsdisease.2018.ch9

\begin{abstract}
Parkinson's disease (PD) manifests with a typical movement disorder, due to the loss of dopaminergic neurons of the substantia nigra. There are no disease-modifying treatments, and current management is centered on symptom control using predominantly dopaminergic drugs. While effective at improving the motor symptoms of PD, these treatments result in significant adverse effects, due to non-targeted and non-physiological delivery of dopamine to the brain. For many years, there has been interest in cell grafting as a potential means of restoring dopamine to the striatum in a physiological manner, which would theoretically treat the symptoms of PD that are due to dopamine deficiency, without the motor and neuropsychiatric adverse effects that are seen with dopaminergic medications. A number of cell sources have been trialed in PD patients, but lack of efficacy, ethical and logistical barriers have meant that most of these do not offer useful treatment options. Stem cell-based treatments are emerging as the most
\end{abstract}

In: Parkinson's Disease: Pathogenesis and Clinical Aspects. Stoker TB, Greenland JC (Editors). Codon Publications, Brisbane, Australia. ISBN: 978-0-9944381-6-4; Doi: http://dx.doi. org/10.15586/codonpublications.parkinsonsdisease.2018

Copyright: The Authors.

Licence: This open access article is licenced under Creative Commons Attribution 4.0 International (CC BY 4.0). https://creativecommons.org/licenses/by-nc/4.0/ 
promising approach for the development of a useful regenerative treatment that could be used in a large number of patients. Although progress in this field has been slow, a number of exciting clinical trials are now on the horizon, and there is genuine hope that stem cells will enter the clinic in the short- to medium-term future.

Keywords: Embryonic stem cell; Induced pluripotent stem cell; Neural grafting; Parkinson's disease; Regenerative therapies

\section{INTRODUCTION}

Parkinson's disease (PD) is a common neurodegenerative disease, which manifests with a characteristic motor syndrome consisting of bradykinesia, rigidity, rest tremor, and as the disease becomes more advanced, postural instability and falls (1). These motor symptoms constitute the syndrome of parkinsonism, which occurs in PD due to the relatively selective loss of dopaminergic neurons of the substantia nigra pars compacta, which results in a reduction in dopamine levels in the striatum $(2,3)$. There are a number of additional non-motor manifestations that occur due to neurodegeneration in other regions, including the cerebral cortex (3). These include sleep disturbance, anosmia, neuropsychiatric features, and cognitive decline (4). Because the motor symptoms of PD occur due to the loss of a specific population of neurons, there has been long-standing interest in whether the function of these neurons could be replaced by regenerative treatments that would restore the dopamine levels in the brain of PD patients (5). This chapter discusses some of the stem cell approaches that are being investigated as a potential means of doing this and where they may fit in the future landscape of PD management.

\section{RATIONALE FOR CELL-BASED THERAPIES FOR PARKINSON'S DISEASE}

There are currently no disease-modifying treatments for PD. The mainstay of current treatment involves the use of dopaminergic drugs to restore the striatal dopamine concentration, with consequent improvement in motor function. These drugs include levodopa (the precursor of dopamine), administered with a peripheral dopa-decarboxylase inhibitor to reduce peripheral side effects, dopamine agonists, and inhibitors of the enzymes that metabolize dopamine (e.g., monoamine oxidase B and catechol-O-methyltransferase). Although these drugs do not alter the course of disease and do not treat the non-motor aspects of $\mathrm{PD}$, they convey a significant benefit in improving the motor symptoms of the majority of patients, particularly in the early stages of the disease.

However, while these drugs offer significant symptomatic benefits, they also result in problematic side effects (6-8). The majority of patients are treated with 
levodopa-based regimes. Administration of levodopa, however, results in dopamine delivery to areas of the brain other than the dopamine-deplete striatum. Consequently, patients experience side effects including hallucinations and cognitive impairment, due to off-target effects of the drug (6). Furthermore, plasma levels of levodopa can be erratic due to variable absorption of the drug, and transit across the blood-brain barrier can be inconsistent (9). This means that patients may develop significant motor fluctuations, with dramatic wearing-off of the drug, which can be particularly problematic (9). Finally, additional involuntary movements may develop in the form of dyskinesias, which are thought to occur due to the continuous nature of dopamine delivery with administration of dopaminergic drugs, which contrasts with the normal pulsatile release of dopamine from nigrostriatal neurons $(7,8)$. Some of these effects can be circumvented by the use of levodopa-intestinal gel, although this is currently very expensive, meaning that it is only used in a minority of patients (10). Deep brain stimulation (DBS), which is discussed in Chapter 8, may also be used in patients with problematic levodopa-induced side effects, although this may also result in significant neuropsychiatric adverse effects and speech problems $(11,12)$.

There is therefore a need for a means of the targeted delivery of dopamine to the striatum, with the dopamine being released in a physiological manner. This would theoretically offer improvements in the motor symptoms of PD patients, while minimizing the off-target side effects, motor fluctuations, and dyskinesias that are seen with levodopa therapy. This could be achieved by the introduction of a graft containing dopamine-producing cells into the patient's striatum. A number of cell sources have been investigated as potential means of doing this (see Table 1). While most of these trials have been unsuccessful for a number of reasons (discussed below), they have offered crucial insights into what is necessary for a cell-based therapy to be effective, and have allowed for significant progress toward a useful cell-based treatment for PD.

\section{TABLE 1 Sources of experimental cell-based treatments for Parkinson's disease}

Cell types trialed in humans

Autografts
Adrenal medullary cells (31-38)
Carotid body cells $(42,43)$
Mesenchymal stem cells (61)

\section{Allografts}

Human fetal ventral mesencephalon $(19-25,27,28)$

Retinal pigment epithelial cells $(40,41)$

\section{Xenografts}

Porcine ventral mesencephalon (44)
Cell types with forthcoming trials in humans

Embryonic stem cell-derived neural progenitors (53)

Induced pluripotent stem cell-derived neural progenitors (53) 


\section{HISTORY OF CELL-BASED THERAPIES FOR PARKINSON'S DISEASE}

In the 1980s and 1990s, there was much interest in the investigation of human fetal ventral mesencephalon (FVM) as a potential source of dopaminergic cells that could be grafted into PD patients. In preclinical studies, it had been seen that the dopaminergic cells in FVM grafts could survive and make synaptic connections in the brains of rodents and that they could result in motor and behavioral improvement (13-18).

Following the promising results of the preclinical trials, human FVM grafting began in patients, with a number of small open-label trials being performed in Sweden. No improvement was seen in the first patients to receive such grafts (19), but by using a greater volume of tissue, and tissue from an earlier gestational age, the majority of patients derived clinical benefits, with some able to discontinue their medications (20-25). At postmortem, it has been seen that these grafts were able to survive for decades, albeit with the development of Lewy body pathology in $11 \%$ of the grafted neurons (26).

The promising results in the Swedish trials led to the initiation of two sham surgery-controlled double-blinded trials in the USA $(27,28)$. In these studies, 56 patients ultimately received human FVM grafts. However, doubt was cast over this approach when these trials reported a high incidence of graft-induced dyskinesias, with little clinical benefit. The development of these dyskinesias has been attributed to the presence of serotoninergic neurons within the transplant, which highlighted the need for a pure population of cells for any graft product $(29,30)$. Additionally, in both of these trials, it was felt that a suboptimal amount of fetal tissue was used, along with inadequate immunosuppression (in one of the trials no immunosuppression was used). While these trials produced disappointing results due to these problems with trial design, they did offer important insight into what was necessary for a cell-based therapy to be effective.

After analysis of all of the available data from the FVM trials that had been carried out, a further open-label trial (TRANSEURO) was commenced in Europe (Clinical trials identifier NCT01898390), which is currently in its follow-up phase. In this trial, patients have received at least three fetal grafts per side, with 12 months of immunosuppression. Although the results of this trial are yet to be published, a positive result will provide convincing proof-of-principle that cellbased therapies can be effective in PD.

Around the same time as the initial preclinical studies of FVM grafts, there was parallel interest in the use of adrenal medullary cells (catecholamine-producing cells that release small amounts of dopamine) as an alternative source of a cellbased therapy for PD. Although these grafts actually survived poorly in the animal models, these adrenal medullary grafts progressed to open-label clinical trials prior to FVM grafts (31-38). Although initially reported to produce promising results, it became clear that any benefit conveyed by these grafts was short-lasting. Significant neuropsychiatric side effects occurred in a number of patients, and at postmortem, it was found that these grafts did not survive, and this approach was therefore abandoned (39). 
Recognizing the failings of the adrenal grafts and the ethical and logistical challenges associated with FVM grafting, a number of other cell sources were considered as potential candidates to serve as the basis for a regenerative therapy for PD. Retinal pigment epithelial cells are able to produce levodopa, as well as potentially beneficial neurotrophic factors. These were initially delivered into the putamina of six PD patients using gelatin microcarrier constructs (40). Initial results were promising with a sustained motor improvement reported, which led to progression to a randomized phase II trial. However, in this trial, it was found that these grafts conveyed no benefit when compared to sham surgery controls and that graft survival was poor (41). Autologous grafts using carotid body cells $(42,43)$ and xenografts using porcine mesencephalon tissue (44) have also been performed in PD patients, with disappointing results.

Importantly, although it had become clear that FVM grafting was not scalable to be used as a mainline treatment for PD predominantly due to logistical barriers and inadequate supply of fetal tissue, the promising results seen in the Swedish trials provided proof-of-principal that neural grafting could serve as the basis for a useful symptomatic treatment in PD. It became clear that it was necessary to develop a renewable source of dopaminergic neurons (or their progenitors) that would be suitable for grafting into a large number of patients. The subsequent discovery of stem cells provided hope that these could fulfil this requirement, and stem cell-based approaches have now become the focus of the field of regenerative medicines for PD.

\section{STEM CELL-BASED APPROACHES}

Stem cells have the potential for self-renewal through unlimited replication, as well as the capacity to differentiate into any cell type within body. The ability to direct the fate of these cells to become a dopaminergic neuron potentially therefore offers an unlimited number of cells that could be used for neural grafting. Although a number of stem cell types have been considered as potential treatment options for PD, the most promising are embryonic stem cells (ESCs) and induced pluripotent stem cells (iPSC) (Figure 1).

\section{Embryonic stem cells}

Human ESCs were first isolated by Thomson in 1998 (45). These are harvested from the inner cell mass of the early blastocyst, and a number of human ESC cell lines have been generated from excess embryos from in vitro fertilization procedures. Over the following decade, differentiation protocols were developed attempting to direct these cells to become dopaminergic neurons (46). While it was possible to induce expression of the rate-limiting enzyme for dopamine synthesis, tyrosine hydroxylase (TH), the yield of TH-positive cells was highly variable (47-49). Nevertheless, these cells were shown to survive transplantation into rodents and to produce a degree of motor recovery (50).

As well as the variable efficacy of the differentiation techniques, it was also clear that although these cells could secrete dopamine, they were not authentic nigral neurons, failing to express LMX1A and FOXA2, which were considered 


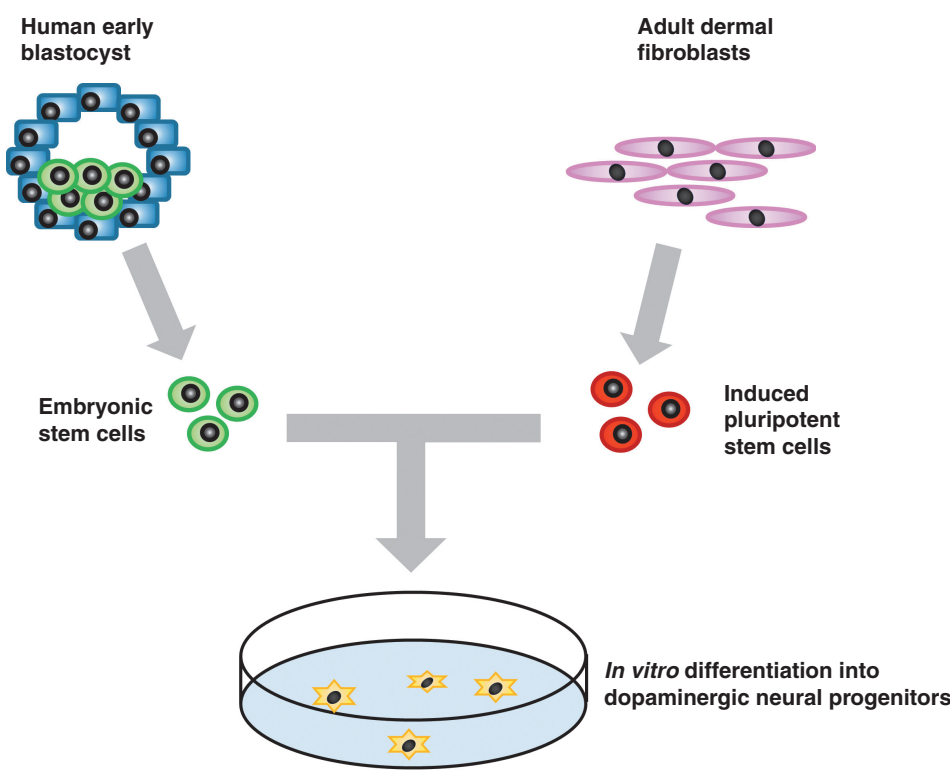

Figure 1 Approaches to stem cell-derived neural grafting in Parkinson's disease.

important markers for nigral dopaminergic neuron phenotype (5). However, the recognition that nigral dopaminergic neurons were of floor plate, rather than neuroepithelial origin, led to the development of new differentiation protocols and the generation of cells that closely resemble authentic nigral dopaminergic neurons (51).

However, as experience of ESC-derived neural cell grafting in animal models has grown, it has become clear that variable yield has remained a problem. An important retrospective study in which over 500 grafts were analyzed sought to identify the factors that determined a successful graft outcome (52). It was found that the grafts containing a high content of $\mathrm{TH}$-positive cells were seen in those grafts that were enriched for neural progenitor cells expressing markers found in 
the caudal midbrain (e.g., CNPY1 and EN1) (52). The markers that had previously been used to indicate nigral phenotype including LMX1A and FOXA2 were also present in rostral midbrain progenitor cells destined for subthalamic nucleus neuron fate. This discovery accounts for the heterogeneity that has been seen with graft outcomes historically and importantly means that it is now possible to generate dopaminergic neuron progenitors at high purity and with high efficiency.

Progress toward an ESC-derived therapy has clearly been iterative, with novel discoveries in neurodevelopmental biology changing the direction of the field several times, as discussed. However, having reached the stage of being able to develop dopaminergic neuron progenitors effectively, the attention is now turning to whether these cells can be clinically useful, and a number of clinical trials of this approach are due to begin (53).

\section{Induced pluripotent stem cells}

In 2007, the process for generating iPSCs was first reported, offering a new avenue for the development of a stem cell-based treatment for PD (and a number of other conditions) (54). iPSCs are generated by the reprogramming of an adult somatic cell (such as a dermal fibroblast) into a stem cell, through the expression of a number of transcription factors that could induce pluripotency (e.g., c-myc, klf-4, sox2, and oct4) (55). The iPSCs derived in this way can be differentiated into dopaminergic neurons using protocols similar to those used with ESCs, which could serve as the basis of a useful cell-based treatment for PD (56). The potential advantage of iPSC-derived over ESC-derived grafts is that it would be possible to generate autologous grafts, by using a patient's own fibroblasts to produce a neural grafting product, negating the requirement for immunosuppression that will be necessary with ESC-derived grafts. However, there are other biological and logistical challenges faced with the iPSC approach, which are discussed below.

iPSC-derived neural grafts have been trialed in primates with MPTP-induced nigral toxicity, with promising results (57). The neural progenitors grafted ultimately extended neurites into the striatum, did not form any tumors, and resulted in improved motor function at two years. As with the ESC-approach, clinical trials in humans are on the horizon and will begin in the next couple of years (53).

\section{Other cell types}

Mesenchymal stem cells can be derived from the bone marrow and have also been considered with regard to development of regenerative treatments in PD. However, although it is possible to generate TH-positive cells, it has not currently been possible to consistently generate authentic midbrain dopaminergic neurons from mesenchymal stem cells; hence, it is unlikely that these will be useful as a cellreplacement therapy for PD (58). These cells have been postulated to have other potential beneficial effects, including anti-inflammatory properties and neuroprotective potential through paracrine activity $(59,60)$. A small cohort of PD patients received mesenchymal stem cell grafts in an open-label study, which demonstrated short-term safety of this approach (61). However, no clinical benefit has been demonstrated, and the future role of these cells remains uncertain. 
An alternative potential means of generating dopaminergic neurons for transplantation is through direct conversion of somatic cells to induced neurons (iNs), through forced expression of proneural transcription factors (62). As with iPSCs, these cells can be derived from patient fibroblasts; therefore, it would be possible to generate autologous neural grafts. Unlike iPSC-derived neurons, there is no stem cell stage to the generation of iNs; hence, they potentially offer an advantage over stem cell sources of dopaminergic neurons, as there is theoretically a reduced risk of tumorigenesis. However, iN reprogramming is less well established than the stem cell approaches, and the results are highly variable (62-66). Furthermore, the number of iNs generated is limited to the number of somatic cells available at the start of a conversion, which is in contrast to the unlimited number of neurons that can be derived from replicating stem cells. Given these limitations, iNs are unlikely to be useful as a cell-based treatment for PD, at least in the short- to medium-term future. There is some interest in the development of in vivo direct reprogramming techniques, in which astrocytes within the host brain are reprogrammed directly into neurons, through introduction of proneural transcription factors with viral vectors (67). While a fascinating prospect, this technique is many years away from being considered as a potential treatment approach, and extensive optimization and investigation of its safety will be necessary. Should the ESC- or iPSC-derived products that are due to enter clinical trials in the shortterm future be shown to be safe and effective, it is unlikely that iNs or other cell sources will emerge as favorable options.

\section{DISADVANTAGES OF STEM CELL APPROACHES}

While the stem cell approaches described potentially offer promising treatment approaches, a number of problems must be overcome in order for them to be used as a mainline treatment for PD.

Of course, any grafting therapy will require a neurosurgical procedure, and it must be demonstrated that this can be achieved safely, with minimal risk. Additionally, for allogenic grafts a period of immunosuppression will be required, with the associated risk of infection and malignancy. Having said this, there is postmortem evidence of FVM graft survival for over two decades, with only a transient period of immunosuppression, and taking into account the fact that the central nervous system is an immune-privileged site, it is unlikely that this will be a major problem (26).

The need for immunosuppression can potentially be circumvented by using autologous grafts derived from iPSCs. This would require generation of a specific neural grafting product for each individual patient. This raises potential regulatory issues, and it may be necessary for each graft product to undergo extensive testing to demonstrate safety, which would make this approach prohibitively expensive (68). The more likely scenario is that it will be necessary to show that the iPSC-reprogramming and differentiation protocols are consistent between all individuals before these products could be approved, which would also carry significant economic expense. This would not be a problem with ESC-derived grafts, as this approach would lead to the development of a single grafting product that would be used for all patients. 
It has been estimated that generating iPSCs from 150 human leukocyte antigen (HLA)-typed individuals could allow for the development of haplobanks which would be able to provide HLA-matched cell products for over $90 \%$ of a population (69). This would mean that rather than an autologous grafting product being produced for each patient, that an iPSC line could be selected with which they were HLA compatible to generate a matched cell product. However, in order to achieve this, a degree of HLA mismatch would be necessary, and a period of immunosuppression would therefore probably be required. Additionally, this would still have significant economic costs (70).

Another potential concern about the use of autologous grafts is that they will carry any genetic risk factors that contributed to the development of PD in the patient. Development of PD pathology has been identified in human FVM grafts at postmortem, and it may be that this process is accelerated in the presence of specific genetic risk factors (26). This may mean that the benefits conveyed by autologous grafts are lost earlier than they would be in allogenic grafts.

Of course, there are ethical considerations that must be taken into account with relation to cell grafting techniques. Historically, ethical objections to the use of human fetal tissue resulted in major challenges to the development of FVM grafting techniques. Generation of ESC-based cell products requires the destruction of a human embryo, which in some societies is also ethically unacceptable. However, in most countries the use of ESCs, derived from human embryos that would otherwise have been discarded, is ethically preferable to the use of fetal tissue, and it is unlikely that this will be a major barrier to the introduction of these treatments (71).

The major safety concern regarding stem cell-based treatments for PD is the potential for tumor formation, which may occur due to graft overgrowth, residual pluripotent cells in the graft, or acquisition of tumorigenic mutations during cell culture. Although tumor formation was seen in some of the early preclinical studies $(47,48,72)$, improvements in differentiation protocols have led to refined cell products of increased purity, which have not caused tumors in animals. Having said this, while tumors have not been seen post-grafting in animals, it must be acknowledged that the grafts are only present in the animals for 1 or 2 years. In contrast, neural grafts would be expected to be present for decades in patients; therefore, rigorous safety data will be necessary to ensure that tumor risk is negligible, even over long periods of time.

It is possible for cultured cells to acquire mutations in oncogenes and tumorsuppressor genes, such as P53, and the significance and potential impact of this is unclear (73). There is a degree of uncertainty with regard to the extent of genetic testing that will be required on any stem cell product, with forthcoming trials planning to adopt different approaches (53). Some trials will perform full genetic sequencing, others will sequence specific genes, and others will perform karyotype analysis only. The significance of any genetic abnormalities identified will need to be established so that the approach to genetic testing can be optimized. For example, identification of a mutation in the BRCA1 gene-a well-established oncogene associated in particular with breast cancer-may be of no clinical significance in dopaminergic neurons grafted into the brain. Uncertainty about the interpretation of genetic screening has led to the cessation of a planned clinical trial of iPSC-derived retinal pigment epithelial cells in patients with macular degeneration, due to the finding of a mutation in a cancer-associated gene. 
Although there was no evidence of tumor formation in preclinical testing of this cell line, the risk that it posed to a potential recipient was not known, and the trial was halted (74).

Finally, if stem cell therapies are to be introduced for the treatment of PD, determination of the optimal patient group will be necessary. It is increasingly clear that PD is a heterogeneous condition, with clinical subtypes emerging (75). Some patients experience motor symptoms only, while others are at high risk of dementia and non-motor manifestations. The stem cell treatments that have been discussed may offer significant symptomatic benefit to those with predominantly motor symptoms but will be of little benefit to patients in which the main problems are non-motor. Public misconception may mean that patients view these treatments as a "cure" for PD; hence, it will be important to convey the fact that these approaches will be symptomatic treatments suitable in appropriately selected patients.

\section{STEM CELL TREATMENTS IN THE FUTURE OF PARKINSON'S DISEASE MANAGEMENT}

Although there are a number of challenges brought about with stem cell-based treatments for $\mathrm{PD}$, it seems probable that these treatments will progress to the clinic in the short- to medium-term future. While development of optimized products has been necessarily slow and iterative, the field is now asking questions about how these treatments can be scaled and delivered-this demonstrates the progress that has been made with these approaches.

As has been discussed, the purpose of stem cell treatments is predominantly to treat the motor symptoms of PD. They will not have any disease-modifying effect and will not treat the major non-motor symptoms which can be particularly disabling in some patients. While these techniques can form one arm of the future of PD treatment, they will likely be combined with other novel treatments targeting alpha-synuclein pathology (e.g., immunotherapies and re-purposed drugs) (76). It may be possible for stem cell-based regenerative therapies to be employed to restore the function of dopaminergic neurons that have already been lost, while novel disease-modifying drugs could be used to prevent ongoing neuronal death.

\section{CONCLUSION}

For the past four decades, there has been much interest in the development of cell-based regenerative therapies, designed to treat the dopaminergic deficits of PD in a physiological manner. However, while a number of cell sources had initially seemed promising, ethical, logistical, and scientific barriers have meant that progress has been slow and iterative. Taking into account historic experiences with other cell sources, stem cell-based treatments have emerged as the most promising means of offering an effective regenerative therapy that could feasibly be scaled for treatment of large numbers of patients. While progress toward clinical trials has taken over a decade, these are now on the horizon. Rather than 
asking whether it is possible to generate a useful cell product, questions asked of this field are now increasingly aimed at answering how these treatments can be delivered to patients, highlighting the progress that has been made toward a cellbased regenerative therapy for PD.

Conflict of interest: The author declares no potential conflict of interest with respect to research, authorship and/or publication of this manuscript.

Copyright and permission statement: To the best of my knowledge, the materials included in this chapter do not violate copyright laws. All original sources have been appropriately acknowledged and/or referenced. Where relevant, appropriate permissions have been obtained from the original copyright holder(s).

\section{REFERENCES}

1. Kalia LV, Lang AE. Parkinson's disease. Lancet. 2015;386(9996):896-912. https://doi.org/10.1016/ S0140-6736(14)61393-3

2. Dickson DW. Parkinson's disease and parkinsonism: Neuropathology. Cold Spring Harb Perspect Med. 2012;2(8). https://doi.org/10.1101/cshperspect.a009258

3. Selikhova M, Williams DR, Kempster PA, Holton JL, Revesz T, Lees AJ. A clinico-pathological study of subtypes in Parkinson's disease. Brain. 2009;132(Pt 11):2947-57. https://doi.org/10.1093/brain/ awp234

4. Khoo TK, Yarnall AJ, Duncan GW, Coleman S, O'Brien JT, Brooks DJ, et al. The spectrum of nonmotor symptoms in early Parkinson disease. Neurology. 2013;80(3):276-81. https://doi.org/10.1212/ WNL.0b013e31827deb74

5. Barker RA, Drouin-Ouellet J, Parmar M. Cell-based therapies for Parkinson disease—past insights and future potential. Nat Rev Neurol. 2015;11(9):492-503. https://doi.org/10.1038/nrneurol.2015.123

6. Young BK, Camicioli R, Ganzini L. Neuropsychiatric adverse effects of antiparkinsonian drugs. Characteristics, evaluation and treatment. Drugs Aging. 1997;10(5):367-83. https://doi. org/10.2165/00002512-199710050-00005

7. Huot P, Johnston TH, Koprich JB, Fox SH, Brotchie JM. The pharmacology of L-DOPA-induced dyskinesia in Parkinson's disease. Pharmacol Rev. 2013;65(1):171-222. https://doi.org/10.1124/ pr.111.005678

8. Jenner P. Dopamine agonists, receptor selectivity and dyskinesia induction in Parkinson's disease. Curr Opin Neurol. 2003;16 Suppl 1:S3-7. https://doi.org/10.1097/00019052-200312001-00002

9. Nutt JG, Woodward WR, Hammerstad JP, Carter JH, Anderson JL. The "on-off" phenomenon in Parkinson's disease. Relation to levodopa absorption and transport. N Engl J Med. 1984;310(8):483-8. https://doi.org/10.1056/NEJM198402233100802

10. Olanow CW, Kieburtz K, Odin P, Espay AJ, Standaert DG, Fernandez HH, et al. Continuous intrajejunal infusion of levodopa-carbidopa intestinal gel for patients with advanced Parkinson's disease: A randomised, controlled, double-blind, double-dummy study. Lancet Neurol. 2014;13(2):141-9. https://doi.org/10.1016/S1474-4422(13)70293-X

11. Kalia SK, Sankar T, Lozano AM. Deep brain stimulation for Parkinson's disease and other movement disorders. Curr Opin Neurol. 2013;26(4):374-80. https://doi.org/10.1097/WCO.0b013e3283632d08

12. Benabid AL. Deep brain stimulation for Parkinson's disease. Curr Opin Neurobiol. 2003;13(6):696706. https://doi.org/10.1016/j.conb.2003.11.001

13. Björklund A, Stenevi U. Reconstruction of the nigrostriatal dopamine pathway by intracerebral nigral transplants. Brain Res. 1979;177(3):555-60. https://doi.org/10.1016/0006-8993(79)90472-4

14. Björklund A, Stenevi U, Dunnett SB, Iversen SD. Functional reactivation of the deafferented neostriatum by nigral transplants. Nature. 1981;289(5797):497-9. https://doi.org/10.1038/289497a0 
15. Perlow MJ, Freed WJ, Hoffer BJ, Seiger A, Olson L, Wyatt RJ. Brain grafts reduce motor abnormalities produced by destruction of nigrostriatal dopamine system. Science. 1979;204(4393):643-7. https:// doi.org/10.1002/ana.410080508

16. Freed WJ, Perlow MJ, Karoum F, Seiger A, Olson L, Hoffer BJ, et al. Restoration of dopaminergic function by grafting of fetal rat substantia nigra to the caudate nucleus: Long-term behavioral, biochemical, and histochemical studies. Ann Neurol. 1980;8(5):510-9. https://doi.org/10.1002/ana.410080508

17. Hoffer B, Freed W, Olson L, Wyatt RJ. Transplantation of dopamine-containing tissues to the central nervous system. Clin Neurosurg. 1983;31:404-16. https://doi.org/10.1093/neurosurgery/31.CN_suppl_1.404

18. Clarke DJ, Dunnett SB, Isacson O, Sirinathsinghji DJ, Björklund A. Striatal grafts in rats with unilateral neostriatal lesions--I. Ultrastructural evidence of afferent synaptic inputs from the host nigrostriatal pathway. Neuroscience. 1988;24(3):791-801. https://doi.org/10.1016/0306-4522(88)90067-X

19. Lindvall O, Rehncrona S, Brundin P, Gustavii B, Astedt B, Widner H, et al. Human fetal dopamine neurons grafted into the striatum in two patients with severe Parkinson's disease. A detailed account of methodology and a 6-month follow-up. Arch Neurol. 1989;46(6):615-31. https://doi.org/10.1001/ archneur.1989.00520420033021

20. Lindvall O, Brundin P, Widner H, Rehncrona S, Gustavii B, Frackowiak R, et al. Grafts of fetal dopamine neurons survive and improve motor function in Parkinson's disease. Science. 1990;247(4942):574-7. https://doi.org/10.1126/science.2105529

21. Brundin P, Pogarell O, Hagell P, Piccini P, Widner H, Schrag A, et al. Bilateral caudate and putamen grafts of embryonic mesencephalic tissue treated with lazaroids in Parkinson's disease. Brain. 2000;123(Pt 7):1380-90. https://doi.org/10.1093/brain/123.7.1380

22. Freeman TB, Olanow CW, Hauser RA, Nauert GM, Smith DA, Borlongan CV, et al. Bilateral fetal nigral transplantation into the postcommissural putamen in Parkinson's disease. Ann Neurol. 1995;38(3):379-88. https://doi.org/10.1002/ana.410380307

23. Kordower JH, Freeman TB, Snow BJ, Vingerhoets FJ, Mufson EJ, Sanberg PR, et al. Neuropathological evidence of graft survival and striatal reinnervation after the transplantation of fetal mesencephalic tissue in a patient with Parkinson's disease. N Engl J Med. 1995;332(17):1118-24. https://doi. org/10.1056/NEJM199504273321702

24. Mendez I, Dagher A, Hong M, Hebb A, Gaudet P, Law A, et al. Enhancement of survival of stored dopaminergic cells and promotion of graft survival by exposure of human fetal nigral tissue to glial cell line--derived neurotrophic factor in patients with Parkinson's disease. Report of two cases and technical considerations. J Neurosurg. 2000;92(5):863-9. https://doi.org/10.3171/jns.2000.92.5.0863

25. Wenning GK, Odin P, Morrish P, Rehncrona S, Widner H, Brundin P, et al. Short- and long-term survival and function of unilateral intrastriatal dopaminergic grafts in Parkinson's disease. Ann Neurol. 1997;42(1):95-107. https://doi.org/10.1002/ana.410420115

26. Li W, Englund E, Widner H, Mattsson B, van Westen D, Lätt J, et al. Extensive graft-derived dopaminergic innervation is maintained 24 years after transplantation in the degenerating parkinsonian brain. Proc Natl Acad Sci U S A. 2016;113(23):6544-9. https://doi.org/10.1073/pnas.1605245113

27. Olanow CW, Goetz CG, Kordower JH, Stoessl AJ, Sossi V, Brin MF, et al. A double-blind controlled trial of bilateral fetal nigral transplantation in Parkinson's disease. Ann Neurol. 2003;54(3):403-14. https://doi.org/10.1002/ana.10720

28. Freed CR, Greene PE, Breeze RE, Tsai WY, DuMouchel W, Kao R, et al. Transplantation of embryonic dopamine neurons for severe Parkinson's disease. N Engl J Med. 2001;344(10):710-9. https://doi. org/10.1056/NEJM200103083441002

29. Politis M, Wu K, Loane C, Quinn NP, Brooks DJ, Rehncrona S, et al. Serotonergic neurons mediate dyskinesia side effects in Parkinson's patients with neural transplants. Sci Transl Med. 2010;2(38):38ra46. https://doi.org/10.1126/scitranslmed.3000976

30. Politis M, Oertel WH, Wu K, Quinn NP, Pogarell O, Brooks DJ, et al. Graft-induced dyskinesias in Parkinson's disease: High striatal serotonin/dopamine transporter ratio. Mov Disord. 2011;26(11):1997-2003. https://doi.org/10.1002/mds.23743

31. Freed WJ, Morihisa JM, Spoor E, Hoffer BJ, Olson L, Seiger A, et al. Transplanted adrenal chromaffin cells in rat brain reduce lesion-induced rotational behaviour. Nature. 1981;292(5821):351-2. https:// doi.org/10.1038/292351a0 
32. Backlund EO, Granberg PO, Hamberger B, Knutsson E, Mårtensson A, Sedvall G, et al. Transplantation of adrenal medullary tissue to striatum in parkinsonism. First clinical trials. J Neurosurg. 1985;62(2):169-73. https://doi.org/10.3171/jns.1985.62.2.0169

33. Lindvall O, Backlund EO, Farde L, Sedvall G, Freedman R, Hoffer B, et al. Transplantation in Parkinson's disease: Two cases of adrenal medullary grafts to the putamen. Ann Neurol. 1987;22(4):457-68. https://doi.org/10.1002/ana.410220403

34. Madrazo I, Drucker-Colín R, Díaz V, Martínez-Mata J, Torres C, Becerril JJ. Open microsurgical autograft of adrenal medulla to the right caudate nucleus in two patients with intractable Parkinson's disease. N Engl J Med. 1987;316(14):831-4. https://doi.org/10.1056/NEJM198704023161402

35. Drucker-Colín R, Madrazo I, Ostrosky-Solís F, Shkurovich M, Franco R, Torres C. Adrenal medullary tissue transplants in the caudate nucleus of Parkinson's patients. Prog Brain Res. 1988;78:567-74. https://doi.org/10.1016/S0079-6123(08)60332-5

36. Kelly PJ, Ahlskog JE, van Heerden JA, Carmichael SW, Stoddard SL, Bell GN. Adrenal medullary autograft transplantation into the striatum of patients with Parkinson's disease. Mayo Clin Proc. 1989;64(3):282-90. https://doi.org/10.1016/S0025-6196(12)65248-3

37. Jiao SS, Zhang WC, Cao JK, Zhang ZM, Wang H, Ding MC, et al. Study of adrenal medullary tissue transplantation to striatum in parkinsonism. Prog Brain Res. 1988;78:575-80. https://doi. org/10.1016/S0079-6123(08)60333-7

38. Goetz CG, Tanner CM, Penn RD, Stebbins GT, Gilley DW, Shannon KM, et al. Adrenal medullary transplant to the striatum of patients with advanced Parkinson's disease: 1-year motor and psychomotor data. Neurology. 1990;40(2):273-6. https://doi.org/10.1212/WNL.40.2.273

39. Jankovic J, Grossman R, Goodman C, Pirozzolo F, Schneider L, Zhu Z, et al. Clinical, biochemical, and neuropathologic findings following transplantation of adrenal medulla to the caudate nucleus for treatment of Parkinson's disease. Neurology. 1989;39(9):1227-34. https://doi.org/10.1212/ WNL.39.9.1227

40. Stover NP, Bakay RA, Subramanian T, Raiser CD, Cornfeldt ML, Schweikert AW, et al. Intrastriatal implantation of human retinal pigment epithelial cells attached to microcarriers in advanced Parkinson disease. Arch Neurol. 2005;62(12):1833-7. https://doi.org/10.1001/ archneur.62.12.1833

41. Gross RE, Watts RL, Hauser RA, Bakay RA, Reichmann H, von Kummer R, et al. Intrastriatal transplantation of microcarrier-bound human retinal pigment epithelial cells versus sham surgery in patients with advanced Parkinson's disease: A double-blind, randomised, controlled trial. Lancet Neurol. 2011;10(6):509-19. https://doi.org/10.1016/S1474-4422(11)70097-7

42. Arjona V, Mínguez-Castellanos A, Montoro RJ, Ortega A, Escamilla F, Toledo-Aral JJ, et al. Autotransplantation of human carotid body cell aggregates for treatment of Parkinson's disease. Neurosurgery. 2003;53(2):321-8; discussion 8-30. https://doi.org/10.1227/01.NEU. 0000073315.88827 .72

43. Mínguez-Castellanos A, Escamilla-Sevilla F, Hotton GR, Toledo-Aral JJ, Ortega-Moreno A, MéndezFerrer S, et al. Carotid body autotransplantation in Parkinson disease: A clinical and positron emission tomography study. J Neurol Neurosurg Psychiatry. 2007;78(8):825-31. https://doi.org/10.1136/ jnnp.2006.106021

44. Schumacher JM, Ellias SA, Palmer EP, Kott HS, Dinsmore J, Dempsey PK, et al. Transplantation of embryonic porcine mesencephalic tissue in patients with PD. Neurology. 2000;54(5):1042-50. https://doi.org/10.1212/WNL.54.5.1042

45. Thomson JA, Itskovitz-Eldor J, Shapiro SS, Waknitz MA, Swiergiel JJ, Marshall VS, et al. Embryonic stem cell lines derived from human blastocysts. Science. 1998;282(5391):1145-7. https://doi. org/10.1126/science.282.5391.1145

46. Kriks S, Shim JW, Piao J, Ganat YM, Wakeman DR, Xie Z, et al. Dopamine neurons derived from human ES cells efficiently engraft in animal models of Parkinson's disease. Nature. 2011;480(7378):547-51. https://doi.org/10.1038/nature 10648

47. Roy NS, Cleren C, Singh SK, Yang L, Beal MF, Goldman SA. Functional engraftment of human ES cell-derived dopaminergic neurons enriched by coculture with telomerase-immortalized midbrain astrocytes. Nat Med. 2006;12(11):1259-68. https://doi.org/10.1038/nm1495 
48. Park CH, Minn YK, Lee JY, Choi DH, Chang MY, Shim JW, et al. In vitro and in vivo analyses of human embryonic stem cell-derived dopamine neurons. J Neurochem. 2005;92(5):1265-76. https:// doi.org/10.1111/j.1471-4159.2004.03006.x

49. Brederlau A, Correia AS, Anisimov SV, Elmi M, Paul G, Roybon L, et al. Transplantation of human embryonic stem cell-derived cells to a rat model of Parkinson's disease: Effect of in vitro differentiation on graft survival and teratoma formation. Stem Cells. 2006;24(6):1433-40. https://doi.org/10.1634/ stemcells.2005-0393

50. Grealish S, Diguet E, Kirkeby A, Mattsson B, Heuer A, Bramoulle Y, et al. Human ESC-derived dopamine neurons show similar preclinical efficacy and potency to fetal neurons when grafted in a rat model of Parkinson's disease. Cell Stem Cell. 2014;15(5):653-65. https://doi.org/10.1016/j.stem.2014.09.017

51. Sánchez-Danés A, Consiglio A, Richaud Y, Rodríguez-Pizà I, Dehay B, Edel M, et al. Efficient generation of A9 midbrain dopaminergic neurons by lentiviral delivery of LMX1A in human embryonic stem cells and induced pluripotent stem cells. Hum Gene Ther. 2012;23(1):56-69. https://doi. org/10.1089/hum.2011.054

52. Kirkeby A, Nolbrant S, Tiklova K, Heuer A, Kee N, Cardoso T, et al. Predictive markers guide differentiation to improve graft outcome in clinical translation of hESC-Based therapy for Parkinson's disease. Cell Stem Cell. 2017;20(1):135-48. https://doi.org/10.1016/j.stem.2016.09.004

53. Barker RA, Parmar M, Studer L, Takahashi J. Human trials of stem cell-derived dopamine neurons for Parkinson's Disease: Dawn of a new era. Cell Stem Cell. 2017;21(5):569-73. https://doi.org/10.1016/j. stem.2017.09.014

54. Takahashi K, Tanabe K, Ohnuki M, Narita M, Ichisaka T, Tomoda K, et al. Induction of pluripotent stem cells from adult human fibroblasts by defined factors. Cell. 2007;131(5):861-72. https://doi. org/10.1016/j.cell.2007.11.019

55. Takahashi K, Okita K, Nakagawa M, Yamanaka S. Induction of pluripotent stem cells from fibroblast cultures. Nat Protoc. 2007;2(12):3081-9. https://doi.org/10.1016/j.cell.2007.11.019

56. Soldner F, Hockemeyer D, Beard C, Gao Q, Bell GW, Cook EG, et al. Parkinson's disease patientderived induced pluripotent stem cells free of viral reprogramming factors. Cell. 2009;136(5): 964-77. https://doi.org/10.1016/j.cell.2009.02.013

57. Kikuchi T, Morizane A, Doi D, Magotani H, Onoe H, Hayashi T, et al. Human iPS cell-derived dopaminergic neurons function in a primate Parkinson's disease model. Nature. 2017;548(7669):592-6. https://doi.org/10.1038/nature23664

58. Offen D, Barhum Y, Levy YS, Burshtein A, Panet H, Cherlow T, et al. Intrastriatal transplantation of mouse bone marrow-derived stem cells improves motor behavior in a mouse model of Parkinson's disease. J Neural Transm Suppl. 2007(72):133-43. https://doi.org/10.1038/nature23664

59. Kim YJ, Park HJ, Lee G, Bang OY, Ahn YH, Joe E, et al. Neuroprotective effects of human mesenchymal stem cells on dopaminergic neurons through anti-inflammatory action. Glia. 2009;57(1):13-23. https://doi.org/10.1002/glia.20731

60. Delcroix GJ, Garbayo E, Sindji L, Thomas O, Vanpouille-Box C, Schiller PC, et al. The therapeutic potential of human multipotent mesenchymal stromal cells combined with pharmacologically active microcarriers transplanted in hemi-parkinsonian rats. Biomaterials. 2011;32(6):1560-73. https://doi. org/10.1016/j.biomaterials.2010.10.041

61. Venkataramana NK, Kumar SK, Balaraju S, Radhakrishnan RC, Bansal A, Dixit A, et al. Open-labeled study of unilateral autologous bone-marrow-derived mesenchymal stem cell transplantation in Parkinson's disease. Transl Res. 2010;155(2):62-70. https://doi.org/10.1016/j.trsl.2009.07.006

62. Vierbuchen T, Ostermeier A, Pang ZP, Kokubu Y, Südhof TC, Wernig M. Direct conversion of fibroblasts to functional neurons by defined factors. Nature. 2010;463(7284):1035-41. https://doi. org/10.1038/nature08797

63. Pereira M, Pfisterer U, Rylander D, Torper O, Lau S, Lundblad M, et al. Highly efficient generation of induced neurons from human fibroblasts that survive transplantation into the adult rat brain. Sci Rep. 2014;4:6330. https://doi.org/10.1038/srep06330

64. Pfisterer U, Kirkeby A, Torper O, Wood J, Nelander J, Dufour A, et al. Direct conversion of human fibroblasts to dopaminergic neurons. Proc Natl Acad Sci U S A. 2011;108(25):10343-8. https://doi. org/10.1073/pnas.1105135108 
65. Pfisterer U, Wood J, Nihlberg K, Hallgren O, Bjermer L, Westergren-Thorsson G, et al. Efficient induction of functional neurons from adult human fibroblasts. Cell Cycle. 2011;10(19):3311-6. https:// doi.org/10.4161/cc.10.19.17584

66. Victor MB, Richner M, Hermanstyne TO, Ransdell JL, Sobieski C, Deng PY, et al. Generation of human striatal neurons by microRNA-dependent direct conversion of fibroblasts. Neuron. 2014;84(2): 311-23. https://doi.org/10.1016/j.neuron.2014.10.016

67. Rivetti di Val Cervo P, Romanov RA, Spigolon G, Masini D, Martín-Montañez E, Toledo EM, et al. Induction of functional dopamine neurons from human astrocytes in vitro and mouse astrocytes in a Parkinson's disease model. Nat Biotechnol. 2017;35(5):444-52. https://doi.org/10.1038/nbt.3835

68. Stoker TB, Blair NF, Barker RA. Neural grafting for Parkinson's disease: Challenges and prospects. Neural Regen Res. 2017;12(3):389-92. https://doi.org/10.4103/1673-5374.202935

69. Taylor CJ, Peacock S, Chaudhry AN, Bradley JA, Bolton EM. Generating an iPSC bank for HLAmatched tissue transplantation based on known donor and recipient HLA types. Cell Stem Cell. 2012;11(2):147-52. https://doi.org/10.1016/j.stem.2012.07.014

70. Blair NF, Barker RA. Making it personal: The prospects for autologous pluripotent stem cell-derived therapies. Regen Med. 2016;11(5):423-5. https://doi.org/10.2217/rme-2016-0057

71. Barker RA, de Beaufort I. Scientific and ethical issues related to stem cell research and interventions in neurodegenerative disorders of the brain. Prog Neurobiol. 2013;110:63-73. https://doi. org/10.1016/j.pneurobio.2013.04.003

72. Sonntag KC, Pruszak J, Yoshizaki T, van Arensbergen J, Sanchez-Pernaute R, Isacson O. Enhanced yield of neuroepithelial precursors and midbrain-like dopaminergic neurons from human embryonic stem cells using the bone morphogenic protein antagonist noggin. Stem Cells. 2007;25(2):411-8. https://doi.org/10.1634/stemcells.2006-0380

73. Merkle FT, Ghosh S, Kamitaki N, Mitchell J, Avior Y, Mello C, et al. Human pluripotent stem cells recurrently acquire and expand dominant negative P53 mutations. Nature. 2017;545(7653):229-33. https://doi.org/10.1038/nature22312

74. Garber K. RIKEN suspends first clinical trial involving induced pluripotent stem cells. Nat Biotechnol. 2015;33(9):890-1. https://doi.org/10.1038/nbt0915-890

75. Williams-Gray CH, Evans JR, Goris A, Foltynie T, Ban M, Robbins TW, et al. The distinct cognitive syndromes of Parkinson's disease: 5 year follow-up of the CamPaIGN cohort. Brain. 2009;132(Pt 11): 2958-69. https://doi.org/10.1093/brain/awp245

76. Brundin P, Dave KD, Kordower JH. Therapeutic approaches to target alpha-synuclein pathology. Exp Neurol. 2017;298(Pt B):225-35. 